\title{
Biology, morphology, and varietal distribution of Saw-toothed grain beetle, Oryzaephilus surinamensis (L) on date palm dry and semi-dry dates at district: Khairpur, Sindh - Pakistan
}

\author{
Tasneem Kousar $^{1 *}$, Zaib-un-Nisa Memon ${ }^{1}$, Hakim Ali Sahito ${ }^{1,2}$, Wali \\ Muhammad Mangrio ${ }^{1}$, Faheem Ahmed Jatoi ${ }^{1}$ and Zafar Hussain \\ Shah $^{1}$ \\ 1. Department of Zoology, Faculty of Natural Sciences, Shah Abdul Latif University, Khairpur Mir's, Sindh- \\ Pakistan \\ 2. Date Palm Research Institute (DPRI), Shah Abdul Latif University, Khairpur Mir's, Sindh-Pakistan \\ *Corresponding author's email: hakim.sahito@salu.edu.pk \\ Citation
}

Tasneem Kousar, Zaib-un-Nisa Memon, Hakim Ali Sahito, Wali Muhammad Mangrio, Faheem Ahmed Jatoi and Zafar Hussain Shah. Biology, morphology, and varietal distribution of Saw-toothed grain beetle, Oryzaephilus surinamensis (L) on date palm dry and semi-dry dates at district: Khairpur, Sindh - Pakistan. Pure and Applied Biology. Vol. 10, Issue 3, pp539-548. http://dx.doi.org/10.19045/bspab.2021.100057

\begin{tabular}{llll}
\hline \hline Received: 19/05/2020 & Revised: 17/10/2020 & Accepted: 21/10/2020 & Online First: 09/10/2020 \\
\hline \hline
\end{tabular}

\section{Abstract}

The biology of saw-toothed grain beetle, $O$. surinamensis was assessed on two different dry and semi-dry dates (Aseel and Dadhi) varieties under laboratory conditions at Date Palm Research Institute, SALU-Khairpur during, 2019-20. The results showed that the overall mean of eggs was observed at $(60.63 \pm 10.41)$ on both varieties and the eggs incubation period $(4.09 \pm 0.50)$, hatching $(82.08 \pm 4.42) \%$ which was almost found higher on dry dates. The duration of various larval stages was also observed from $1^{\text {st }}$ stage larvae to $4^{\text {th }}$ stage $(2.95$ to 7.09$)$ in days thus, the mortality and survival rate with $\%$ at (4.78 to 46.32$)$ and (3.56 to 88.34) with the pupae period was (12.24). While as; an adult male (10.84) and female (15.91) days consumption and total life spawn (46.78) and (51.86) with a sex ratio (0.90) and (1.11) was remained fluctuated, thereof the maximum infestation on Dadhi dry fruit was observed $(9.45 \pm 1.28)$, semi-dry $(9.01 \pm 6.44)$ and

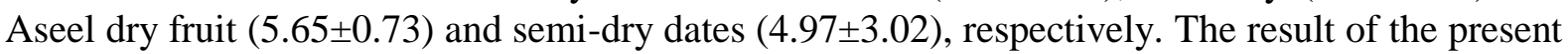
work indicates that this insect pest frequently relay a negative effect on both types of fruits but the high peak of infestation observed during September and October. It was calculated that $3^{\text {rd }}$ and $4^{\text {th }}$ larvae found a voracious feeder that gently hits dates fruit. The present investigation suggested that there is a vital need to introduce environment-friendly integrated pest management techniques and sufficient measures to secure this golden industry of this region.

Keywords: Aseel; Dadhi; Fluctuations; Incubation; Khairpur; Phoenix dactylifera

\section{Introduction}

The sawtoothed grain beetle, Oryzaephilus surinamensis Linnaeus (Coleoptera: Silvanidae), is one of the keys stored grain pests that occur globally $[1,2]$. Although the biology of $O$. surinamensis has been studied by many researchers [3] on various hosts, detailed studies on the biology of $O$. surinamensis on semi-dry and dry dates is not documented properly. This insect is 
highly sensitive to reach stored foods stuffs due to fruit fragrance and they make attempt to find their way to reach food availability [4], but in UAE, Tunisia, Saudi Arabia, Jordon, Egypt, Algeria, Sudan, and Pakistan saw-toothed grain beetle is a most important pest of stored dates [5], but dates are widely attacked by $O$. surinamensis both at field conditioning and stock places. The larvae of this pest insect create quality and quantity degradation; reduce the germination power of the seed, and lowering the date's nutritional value and dates fruit are attacked by $O$. surinamensis both at the field and stock stuff [6]. The larval infestation of $O$. surinamensis severely reduces the essential amino acids, lipids, polar, and no polar lipids, phospholipids, methionine, galactolipids, lysine, and isoleucine [7]. The beetle distribution is affected by many factors such as processing practices, availability of food, the interaction between species and temperature conditions but frequently found and serve best in pantry areas [8].

The $O$. surinamensis are small-sized insects and at storage places, they hide due to this nature it is difficult to control them through the application of insecticides [9]. There are three genera of Oryzaephilus and all these genera possess a series of teeth like appearance behind the eyes projection [10]. Female and male are nearly morphologically similar but the male has a posterior margin on hind trochanter and medially spine-like projection and margin at the upper hind femur [11].

The saw-toothed grain beetles are almost omnivorous in their feeding behavior. It is necessary to update all feeding habits in response to introducing sustainable and suitable control measures to reduce infestation attacks [12]. These pests also cause disease problems and retard the growth of date palm trees [13]. Many scholars used their stamina to perform the study on the profit of dates from its seeds or fruits, antifungal, hepato-protective activities, antiviral, and antioxidant [14]. The present research study shows the biological, morphological investigation of the saw-toothed grain beetle on Aseel and Dadhi varieties of stored dried and semi dries dates commodities. In District; Khairpur Mir's about 20\% dates fruit is destroyed due to insufficient methods and poor management here only two research institutes are operational, date palm research institute at Kot Diji, and next is at Shah Abdul Latif University Khairpur. It is of paramount importance to know about the biology and life table parameters of this pest. Prevention of losses in stored products due to insect pests is of paramount importance. Hence; the present investigations on biology and morphology of this insect on two stored commodities are informative and crucial for developing management practices. By characterizing host-associated genetic variation in this cosmopolitan insect we attempted to obtain basic information with the potential to be used for future strategies.

\section{Materials and Methods}

\section{Collection of $\boldsymbol{O}$. surinamensis}

For the proper biological study, two pestinfested dates varieties namely; $\mathrm{T} 1=$ Dadhi, T2= Aseel (semi-dry dates), T3= Dadhi and $\mathrm{T} 4=$ Aseel (dry dates) were collected from the stores, houses, shops, homes and mostly from Khajoor and Chuhara mandy of district: Khairpur for the purpose to conduct the biology and morphology parameters of this pest during the consequent years from May 2019 to April 2020. After collection infested dates were poured into plastic jars and brought under laboratory conditions for culture maintenance. The laboratory research work was carried out at Date Palm Research Institute (DPRI), Shah Abdul Latif University, Khairpur during, 201920.

\section{Mass-rearing}

The infested dates placed in plastic jars containing $1.5 \mathrm{~kg}$ capacities were used and jars kept incubated at room temperature $25 \pm 2{ }^{\circ} \mathrm{C}$ and $60-70 \%$. During the eggs hatching process, the focus was taken from egg to adult stages such as; incubation 
period, female fecundity, egg fertility, larval survival rate, larval developmental stages, adult longevity, the sex ratio of males and females were observed. The couples were identified and separated by using of stereomicroscope under laboratory conditions and placed in $18 \mathrm{~cm} \mathrm{x}$ 12 plastic cylindrical dimension containing Aseel and Dadhi dry and semi-dry verities of dates as a source of food and for female oviposition media covered with the muslin cloth with rubber band secured it to provide restriction for external insects and avoid the escape of trapped insects. For the proper observations, the jars were arranged in row manner. Again for authentic conformation observation was replicated five times. When female laid eggs inside the plastic jars which were taken by the source of camel hairbrush and placed into separate jars for hatching and observation of different life stages. Mortality and survival of different stages of the pest formulated by using the following formula:

The rate of mortality $=$ No. of dead insects/Total no. of insects x 100

Survival percentage $=$ No. of survival insects/Total no. of insects x 100

Again for the population fluctuation on dry and semi-dry date fruits were collected from godowns at Khairpur Khajoor mandi and brought under laboratory conditions at a fortnightly interval basis and the sawtoothed population was counted by the help of magnifying glasses. The purpose was to find out which variety is severely affected than others and to determine the choice and no-choice of varieties. For this purpose, the most resistant and susceptible variety was highlighted in this research work besides, the most divesting stage was kept under observation.

\section{Morphological attributions}

During laboratory conditions, the attention was taken on all morphological attributions of the saw-toothed grain beetle, $O$. surinamensis such as; size and shape of eggs, the morphology of larvae with changing coloration, an adults morphological variation weight, and size, etc.

\section{Statistical analysis}

The analysis of variance was made through the randomized complete block design of all biological parameters and means were separated through (LSD) test at 5\% probability to measure up the different treatments through the help of student package statistics software 8.1 versions, USA.

\section{Results}

The biology of $O$. surinamensis on two date varieties (Aseel and Dadhi) indicated the different life stages but the duration of egg incubation, larval period, and all other stages found varied between both varietal dates' fruit with certain fluctuations during the consequent months of both years, 2019-20. The maximum eggs were laid on Dadhi variety as compared to Aseel variety in both dried and semi-dried conditions. During a year study plan overall egg hatching percentage on Dadhi variety was observed (90.57 to 72.37) and Aseel variety (88.47 to 76.91) as described an under given (Table 1). The larval mortality percentage was also observed at (19.76 to 6.46) and (15.44 to 4.94), larval survival percentage (93.53 to 80.24), (95.05 to $84.55)$ and pupal period (13.45 to 8.30), (15.83 to 11.36) (Table 2), and male consumed minimum days and with minimum sex ratio as compared with female. The male life span on Dadhi variety ranges from (6.55 to 15.82) and on Aseel variety consumed (9.59 to 11.38) days. The female on Dadhi variety consumed (15.38 to 17.85) days and on Aseel variety (11.05 to 19.35) days as presented in (Table 3). The overall mean of population fluctuation on both varieties was also observed (9.01 to 9.45) and (4.97 to 5.65), respectively. When statistical data were analyzed that shows the significant difference among all stages of pest and least significant differences were found varied from each other. 
Table 1. Overall mean and SD of egg developmental stages of $O$. surinamensis on Dadhi and Aseel varieties under laboratory conditions at DPRI

\begin{tabular}{|c|c|c|c|c|c|}
\hline \multirow{2}{*}{$\begin{array}{l}\text { Dates fruit } \\
\text { varieties }\end{array}$} & \multirow{2}{*}{$\begin{array}{c}\text { Female eggs } \\
\text { laid }\end{array}$} & \multirow{2}{*}{$\begin{array}{l}\text { Egg incubation } \\
\text { period (days) }\end{array}$} & \multicolumn{3}{|c|}{ Egg fertility } \\
\hline & & & Hatched & $\begin{array}{c}\text { Un- } \\
\text { hatched }\end{array}$ & Hatching \% \\
\hline $\begin{array}{l}\text { Aseel (semi-dry } \\
\text { dates) }\end{array}$ & 40.55 & 3.50 & 29.35 & 11.20 & 72.37 \\
\hline $\begin{array}{c}\text { Dadhi (semi-dry } \\
\text { dates) }\end{array}$ & 45.05 & 3.04 & 34.65 & 10.40 & 76.91 \\
\hline Aseel dry dates) & 75.35 & 4.55 & 68.25 & 7.10 & 90.57 \\
\hline Dadhi (dry dates) & 81.55 & 5.25 & 72.15 & 9.40 & 88.47 \\
\hline Mean+SD & $60.63 \pm 10.41^{a}$ & $4.09 \pm 0.50^{\mathbf{b}}$ & $51.51 \pm 11.11^{\mathrm{a}}$ & $9.53 \pm 0.89^{b}$ & $82.08 \pm 4.42^{\mathrm{a}}$ \\
\hline
\end{tabular}

Table 2. Overall mean and SD of different stages of $O$. surinamensis on dates of two host date palm trees under laboratory conditions

\begin{tabular}{|c|c|c|c|c|c|c|c|c|c|}
\hline \multirow{2}{*}{$\begin{array}{l}\text { Dates } \\
\text { varietie } \\
\quad \mathbf{s}\end{array}$} & \multicolumn{4}{|c|}{$\begin{array}{c}\text { Duration of different larval stages } \\
\text { in days }\end{array}$} & \multicolumn{5}{|c|}{ Larval and Pupal stages } \\
\hline & $\begin{array}{c}1^{\text {st }} \\
\text { stage }\end{array}$ & $\begin{array}{c}2^{\text {nd }} \\
\text { stage }\end{array}$ & $\begin{array}{c}3^{\text {rd }} \\
\text { stage }\end{array}$ & $\begin{array}{c}4^{\text {th }} \\
\text { stage }\end{array}$ & $\begin{array}{l}\text { Mortali } \\
\text { ty rate }\end{array}$ & $\begin{array}{c}\text { Surviva } \\
\text { I rate }\end{array}$ & $\begin{array}{l}\text { Mortali } \\
\text { ty \% }\end{array}$ & $\begin{array}{l}\text { Surviva } \\
1 \%\end{array}$ & $\begin{array}{l}\text { Pupae } \\
\text { period }\end{array}$ \\
\hline $\begin{array}{c}\text { Aseel } \\
\text { (semi- } \\
\text { dry) }\end{array}$ & 1.50 & 2.68 & 4.88 & 6.80 & 5.80 & 23.55 & 19.76 & 80.24 & 11.36 \\
\hline $\begin{array}{l}\text { Dadhi } \\
\text { (semi- } \\
\text { dry) }\end{array}$ & 2.50 & 3.65 & 3.90 & 5.95 & 5.35 & 29.30 & 15.44 & 84.55 & 8.30 \\
\hline $\begin{array}{l}\text { Aseel } \\
\text { dry) }\end{array}$ & 3.85 & 5.30 & 5.20 & 7.35 & 4.41 & 63.84 & 6.46 & 93.53 & 15.83 \\
\hline $\begin{array}{l}\text { Dadhi } \\
\text { (dry) }\end{array}$ & 3.95 & 6.20 & 6.55 & 8.25 & 3.57 & 68.58 & 4.94 & 95.05 & 13.45 \\
\hline $\begin{array}{l}\text { Mean+ } \\
\text { SD }\end{array}$ & $\begin{aligned} 2.95 \pm \\
0.59^{\mathrm{c}}\end{aligned}$ & $\begin{array}{c}4.46 \pm 0 . \\
79^{\mathrm{c}}\end{array}$ & $\begin{array}{c}5.13 \pm 0 . \\
55^{\mathrm{c}}\end{array}$ & $\begin{array}{c}7.09 \pm 0 . \\
48^{c}\end{array}$ & $\begin{array}{c}4.78 \pm 0 . \\
50^{\mathrm{c}}\end{array}$ & $\begin{array}{c}46.32 \pm 1 \\
1.59^{\mathbf{b}} \\
\end{array}$ & $\begin{array}{c}3.56 \pm 11 \\
.65^{\mathrm{c}}\end{array}$ & $\begin{array}{c}88.34 \pm 3 \\
.56^{\mathrm{a}} \\
\end{array}$ & $\begin{array}{c}12.24 \pm 1 \\
.60^{c}\end{array}$ \\
\hline
\end{tabular}

Table 3. Overall mean life longevity on Aseel and Dadhi (semi-dry and dry dates) varieties under laboratory conditions

\begin{tabular}{|c|c|c|c|c|c|c|}
\hline \multirow{2}{*}{$\begin{array}{c}\text { Dates fruit } \\
\text { varieties }\end{array}$} & \multicolumn{2}{|c|}{ Adults (days) } & \multicolumn{2}{c|}{ Life spawn } & \multicolumn{2}{c|}{ Sex ratio } \\
\cline { 2 - 7 } & Male & Female & Male & Female & Male & Female \\
\hline $\begin{array}{c}\text { Aseel } \\
\text { (semi-dry) }\end{array}$ & 6.55 & 15.38 & 37.27 & 46.10 & 0.80 & 1.23 \\
\hline $\begin{array}{c}\text { Dadhi } \\
\text { (semi-dry) }\end{array}$ & 9.59 & 11.05 & 36.93 & 38.39 & 0.96 & 1.03 \\
\hline Aseel dry) & 15.82 & 17.85 & 57.90 & 59.93 & 0.96 & 1.03 \\
\hline $\begin{array}{c}\text { Dadhi } \\
\text { dry) }\end{array}$ & 11.38 & 19.35 & 55.03 & 63.00 & 0.87 & 1.14 \\
\hline Mean+SD & $\begin{array}{c}10.84 \pm 1.94 \\
\mathbf{b}\end{array}$ & $15.91 \pm 1.81^{\mathbf{b}}$ & $46.78 \pm 5.62^{\mathbf{a}}$ & $51.86 \pm 5.80^{\mathbf{a}}$ & $0.90 \pm 0.04^{\mathbf{c}}$ & $1.11 \pm 0.05^{\mathbf{c}}$ \\
\hline
\end{tabular}


The infestation of $O$. surinamensis on dried and semi-dried Dadhi and Aseel varieties

The Dadhi and Aseel dried and semi-dried varieties were collected from different stock places at district Khairpur Mirs and carefully observed that found with the prevalence of different stages of the sawtoothed grain beetle when brought under laboratory conditions at Date palm research institute, SALU-Khairpur. The maximum pest population was found during warmer months and the minimum pest population when the temperature falls in the winter season. The data were statistically analyzed and means were compared within an egg laid, incubation hatched, and unhatched percentage $(\mathrm{DF}=$ 4, 3; $\mathrm{F}=37.30 ; \mathrm{P}=0.000)$ which were found significantly different from each other. Whereas; the larval days consumption, mortality rate and percentage, survival rate and percentage and pupal period on both varieties shows significant difference at $(\mathrm{DF}=8,3 ; \mathrm{F}=$ 47.39; $\mathrm{P}=0.001$ ), and male/female days consumption, life span and sex ratio on same varieties $(\mathrm{DF}=5,3 ; \mathrm{F}=67.66 ; \mathrm{P}=$ 0.001) also found significantly different, respectively.

\section{Population fluctuation of Saw-toothed grain beetle on (dry and semi-dry dates fruits on Dadhi and Aseel varieties}

When the semi-dry dates were reached at the Khajoor and Chuhara mandi, district: Khairpur during the season, 2019-20. In the month of first May, samples of about 100 semi-dry and dry dates of two different varieties were purchased from the stored godowns of dates for checking the population variation on a fortnightly interval basis throughout the year. Thus, the peak population was observed from September to October and the least population was observed from January to February. Among both varieties, the Dadhi variety found most vulnerable with the saw-toothed grain beetle on semi-dry dates whereas, the Aseel variety was found less affected with pest, $O$. surinamensis on semi-dry and dry dates of the market. The analysis of variance shows the nonsignificant difference every month started from May 2019 to April 2020 on semi-dry dates at $(\mathrm{DF}=1,23 ; \mathrm{F}=1.154 ; \mathrm{P}=0.2270)$, respectively (Fig. 1). Whereas; the analysis of variance shows the significant difference among these months fortnightly interval basis data $(\mathrm{DF}=23,1 ; \mathrm{F}=4.97$; $\mathrm{P}=0.0001)$ as described in under given (Fig. 2), respectively.

\section{Morphological description of saw- toothed grain beetle}

Female of the $O$. surinamensis, laid fresh eggs in a single manner which found whitish in color and oval in shape, as time passed those smoothly became dark brownish as found near to hatching stage into larval stages (Fig. 3). The first stage larvae were observed whitish and somewhat moved very slowly around the food masses thus, the second stage of larvae was observed whitish but anteriorly contained brownish pigmentation and posteriorly pointed body. At this stage, the larvae gradually moved for food purposes likewise, the third stage of larvae contained the elongated body, yellowish to whitish. In this stage, the jointed appendages found visible in the thoracic region. At this stage, the larvae found posterior blunt and anteriorly head with antennae and have more need of food for their survival. The fourth stage larvae observed more active as compared to other stages and severely infested the date fruits. This stage of larva found brownish and anteriorly much darker brown and at head region contained paired antennae and eyespots at the head region. Pupae color is found much darker and brown with a constricted body. Pupae are also found with protected cocoon layers. Like the passing of a few days, the anterior silt-like appearance occurred and the new adult emerged. Adults were dark brown an active insect, slender shaped, having 2 to $3 \mathrm{~mm}$ in size, with characteristic teeth like running down the side of the prothorax with smaller eyes with broader and 
triangular-shaped head. A tooth on the femur of the hind legs makes differentiation in males from the female. A paired beadle shaped antennae used for certain behavioral activities, further as described as in hand made diagrams as given as under.

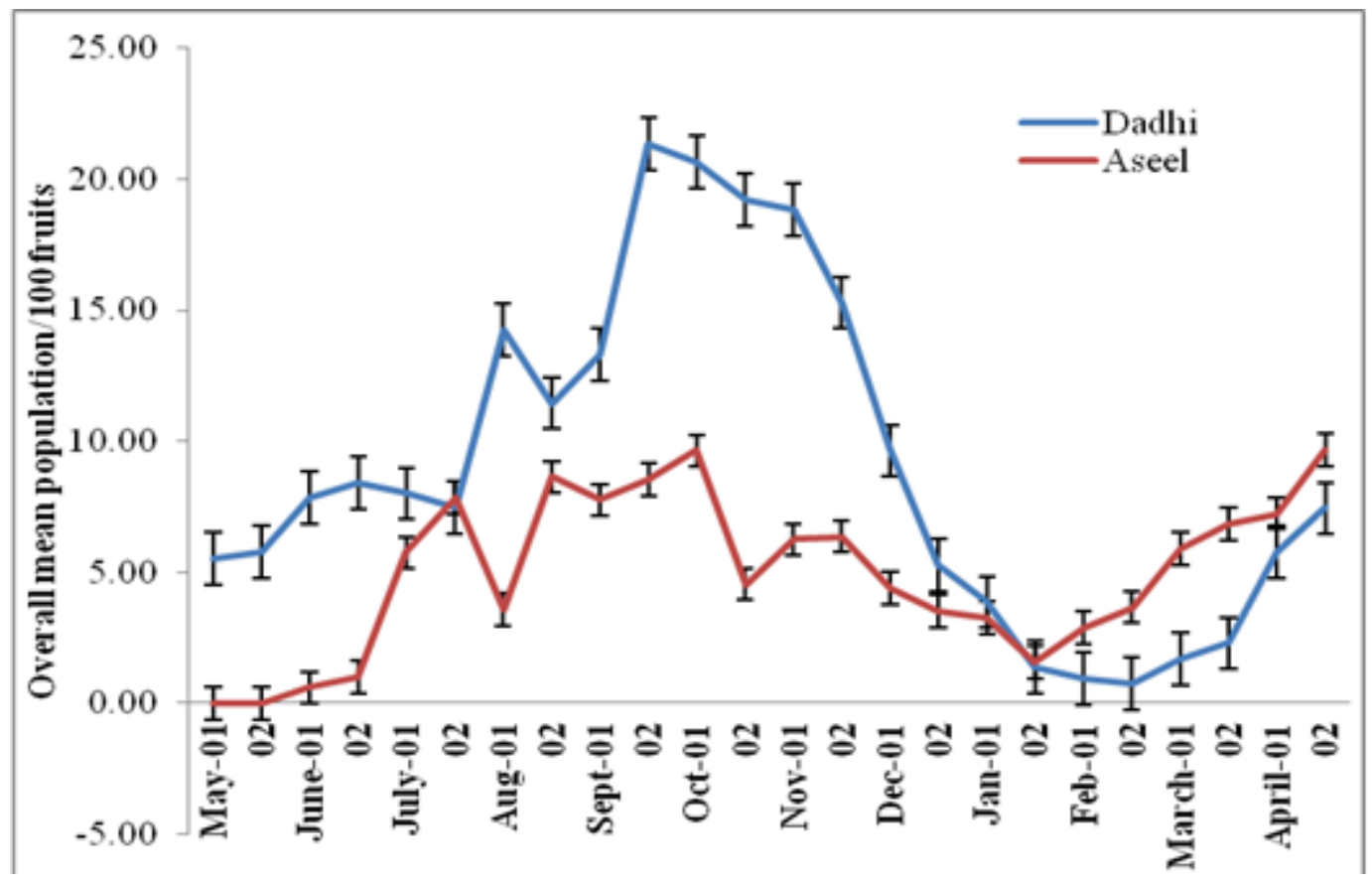

Figure 1. The fortnightly overall mean population of $O$. surinamensis on semi-dry dates during, 2019-20

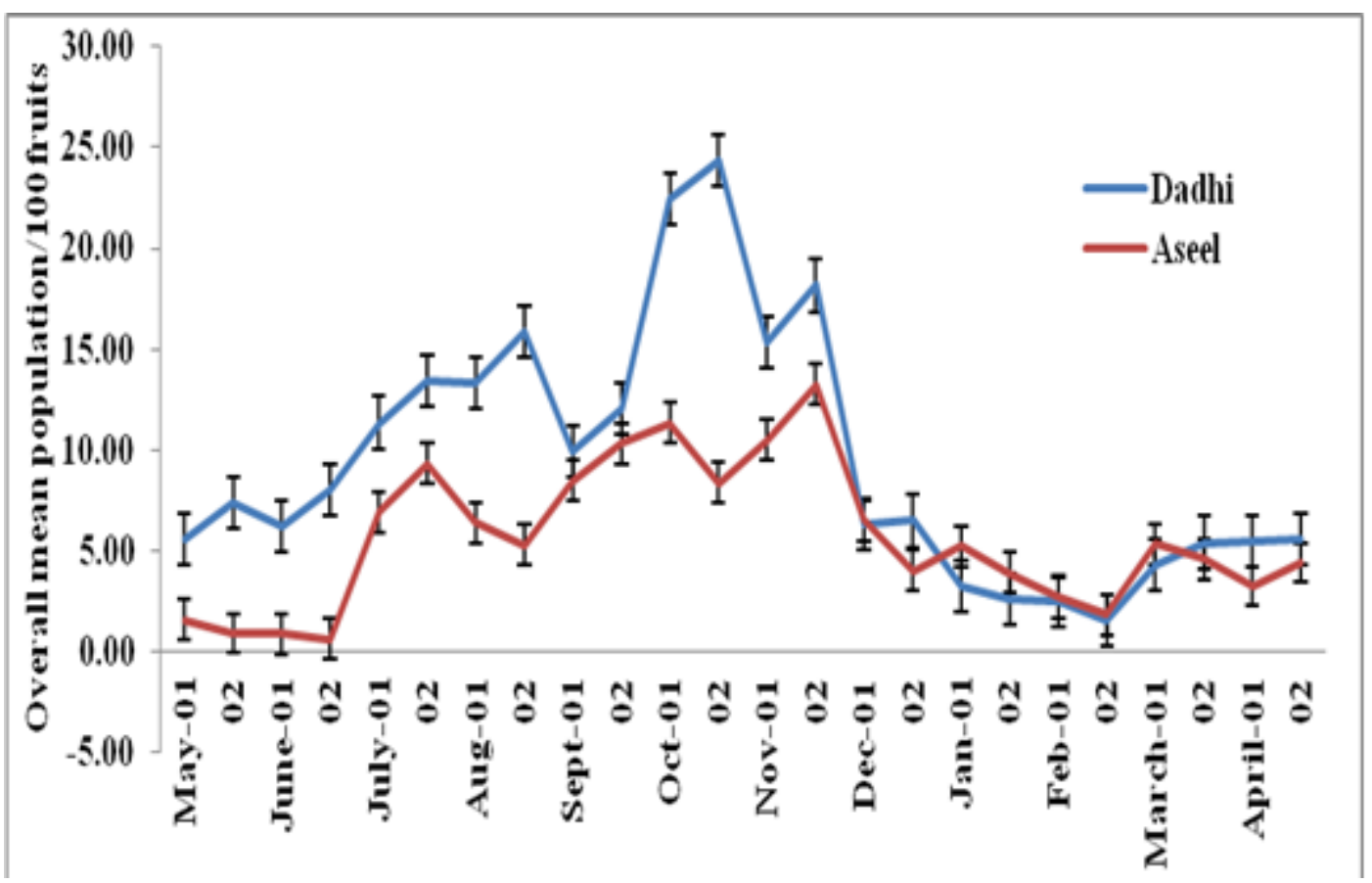

Figure 1. The fortnightly overall mean population of $O$. surinamensis on dry dates/Chuhanra during, 2019-20 


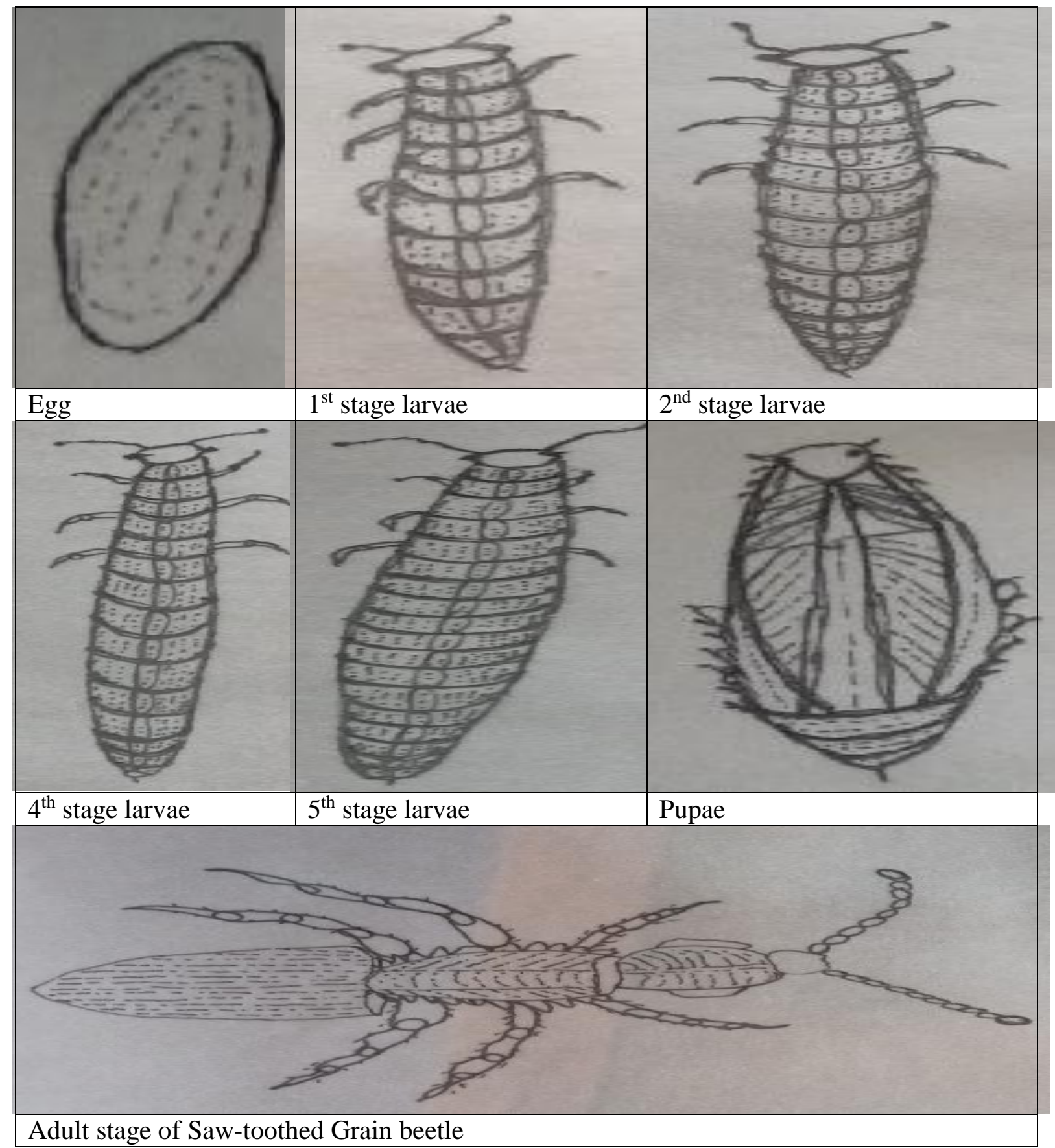

Figure 3. Handmade diagrams of different life cycle stages of Saw-toothed grain beetle under laboratory conditions at DPRI

\section{Discussion}

In the world, there are ten topmost dates fruit-producing countries including; Saudi Arabia, United Arab Emirates, Sudan, Egypt, Pakistan, Oman, Iran, Tunisia, Algeria, and Libya amongst Pakistan ranks $6^{\text {th }}$ biggest dates producing country and in these countries date, palm fruit-bearing crop is considered as more important than other crops [15]. The Phoenix is a Greek word meaning red fruit and dactylifera means finger-like appearance [16]. The date palm trees having the capability to survive in salinity, drought, at upper range temperatures also with other many crops hence sometimes called symbol of life in the desert regions [17]. The Muslim communities widely in a daily manner had 
been using dates fruit during Ramadan [18] used for fuel, leaflets to weave fruit baskets and mats also to build homes [19] and their fruit is on the top of the list [20].

Dates are the source of health and nutritional value, riches content of antioxidants, contain ferulic acid, coumaric acid, moreover, it consists fructose, glucose, sucrose, sterols, anthocyanins, flavonoids, carotenoids, dietary fibers, procyanidins, fats, proteins, biotin, folic acid, riboflavin, ascorbic acid, thiamine, copper, potassium, calcium, phosphorus, iron, sodium, cobalt, boron, magnesium, selenium, zinc and fluorine [21]. Certain factors relying a negative effect on date production, mainly in the cultivation of dates including, planting of mixed seedling or cultivars, crowding of trees, unproductive trees, poor drainage, salt accumulation, insufficient tilling or fertilization, irrigation, soil degradation, water scarcity and lack of disease control and pest management [22]. The $O$. surinamensis is mainly pantry pest, secondary feeders, by forming minor lesions or crakes became successful to enter the dates [21]. Due to the critical infestation of this pest dried and semidried dates reduce the quality and quantity and weight loss as well and by the help of the chewing type of mouth reach foodstuffs and move inside the food packed boxes.

Our results having certain similarities with the findings of [22], they studied biological study, food preference, host range, and type of food, and [23], they documented infestation on stored dates. The present work is comparable with the findings of [24] authors studied the biology of saw-toothed grain beetle but due to high mobility and smaller size it is difficult to get sufficient offspring during the rearing process and with the work of [8], he documented that each stage larvae molt moves them into next stage and adults found $2.5 \mathrm{~mm}$ in their length. Larvae into cracks crawl. The present findings are furthermore related to the findings of [25], they reported, $O$. surinamensis lay the eggs in the dried and semi-dried dates after hatching larvae can larvae develop. The adult female lays their eggs in singly at the area of food supply and near about two months egg to adult arise female adult serve their life from six to ten months may live three years if the environmental conditions are fruitful. Our findings are also with the agreement of [26] who documented biology, morphology, and taxonomy of lesser date moth on dates at the same district on two different temperatures under laboratory conditions. Keeping in view, it is firmly needed to know about the rate of losses during the developmental stages of the pest insect and introduce the crucial and informative management strategies to minimize the losses from the vigorous pest insects during storage periods. In present findings, it was positively found the infestation attacks on both varieties throughout the year but significant development prolongation and shortening duration found with low and high fluctuations. In present scientific-based researches investigating the biology of insects on the fruit of two different varieties were observed and attention was given their severe losses. In this context, basic knowledge and sustainable management practices are needed to minimize the storage product losses.

\section{Conclusion and recommendations}

The biological study of $O$. surinamensis on dates was performed the first time in this area and focus was taken on Dadhi and Aseel varieties during present work. Phoenix dactylifera locally called Khajoor and dates trees are the main source of the live hood of the district: Khairpur, it was frequently concluded that this insect pest is widely harming dry and semi-dry dates fruit of Aseel and Dadhi verities throughout the year but mostly at stock places. Aseel dates are the most economical and valuable known as queen variety of this area. In present research findings, the fruit of Dadhi and Aseel 
variety (dry and semi-dry) were observed with less infestation in the May month and with high infestation during October. Similarly, the minimum pest population was observed on dry dates during May and maximum in September. The present work is recommended that will be supportive and informative to know about this pest insect and its $O$. surinamensis harmful hazards.

\section{Author's contributions}

The experiments were designated and conceived: ZN Memon \& HA Sahito, Performed experiments by: $\mathrm{T}$ Kousar, Analyzed the data: WM Mangrio, Tools/ analyses/ materials by: FA Jatoi \& $\mathrm{ZH}$ Shah.

\section{Acknowledgment}

The authors are highly thankful to local growers and date palm owners of this area for sharing fruitful ideas and there experience about date palm varieties and their date fruits. Again authors cheerfully pleased to their Co-guide Dr. Hakim Ali Sahito for their admiral approaches, expertise, and restless approaches which poured the soul of encouragement amongst us. His revolutionary ideas lead us to this leading pathway by which we have attended this attempt.

\section{References}

1. Hashem MY, Ahmed SS, ElMohandes MA \& Gharib MA (2012). Susceptibility of different life stages of saw-toothed grain beetle Oryzaephilus surinamensis (L.) (Coleoptera: Silvanidae) to modified atmospheres enriched with carbon dioxide. J of Stored Product Res 48: 46-51.

2. Rossiter LC, Gunning RV \& Rose HA (2001). The use of polyacrylamide gelelectrophoresis for the investigation and detection of fenitrothion and chlorpyrifos-methyl resistance in $O$. surinamensis (Coleoptera: Silvanidae). Pesti Biochemist Physiolo 69: 27-34.

3. Mallah NA, Sahito HA, Kousar T, Kubar WA, Jatoi FA \& Shah ZH
(2016). Susceptibility of different varieties of stored date palm fruits infested by saw tooth grain beetle, $O$. surinamensis (L. 1758) under laboratory conditions. J Entomo and Zool Studi 4(6): 1-96.

4. Najeeb MA (2001). Pests and diseases of date palm. Ministry of Agriculture and water. extension directorate. Kingdom of Saudi Arabia.

5. Thomas EL \& Shepard HH (1940). The influence of temperature, moisture, and food upon the development and survival of the sawtoothed grain beetle. J Agri Res 60: 605-615

6. Kumar TP, Moorthy SN, Balagopalan C, Jayaprakas CA \& Rajamma P (1996). Quality changes in market cassava chips infested by insects. $J$ Stored Products Res 32(2): 183-186.

7. Trematerra P \& Sciarretta A (2004). Spatial distribution of some beetles infesting a feed mill with spatiotemporal dynamics of Oryzaephilus surinamensis, Tribolium castaneum and Tribolium confusum. J Stored Produ Res 40(4): 363-377.

8. Heather NW \& Wilson D (1983). Resistance to fenitrothion in $O$. surinamensis (L.) (Coleoptera: Silvanidae) in Queensland. J Austri Ento Soc 22-210.

9. Mason LJ (2003.) Grain insect fact sheet. Cooperative Extension Service. Dept Entomol Purdue Univ pp. 228.

10. Lobl I \& Kodada J (1996). Redescription of adult Bledioschema schweigeri Coleoptera: Staphylinidae: Oxytelinae) with description of its presumed larva and taxonomic comments. Eur J Entomol 93: 629639.

11. Astuti L Mario MB \& Widjayanti T (2018). Preference, growth and development of $O$. surinamensis (L.) (Coleoptera: Silvanidae) on red, white and black rice in whole grain and flour form. J Ento Res 42(4): 461-468 
12. Erskine (2003). Date-palm in the GCC countries of the Arbalian Peninsuula

htt://www.incarda.org/app/date palm introduction/into-body.htm.

13. Al-Farsi MA \& Lee CY (2008). Nutritional and functional properties of dates: a review. Critical Rev of Food Sci and Nutr 48: 877-887.

14. Abul-Soad AA, Markhand GS \& Memon S (2010). Bags impact on dates. The final report. DuPont Pakistan operations (Pvt.) Ltd, 2G-4, Johar Town, Canal Bank Road, Lahore-54790, Pakistan.

15. Zaid A, de Wet PF, Djerbi M \& Oihabi A (2002). Diseases and pests of date palm, in: Zaid A and Arias, EJ (ed.). Date palm cultivation. Rev 1. FAO Plant Produ and Protec 227281.

16. Lunde P (1987). A history of dates. Saudi Aramco World 29(2): 176-179.

17. Kader AA \& Hussein A (2009). Harvesting and post-harvest handling of dates. The Inter Cent for Agri Rese in the Dry Areas (ICARDA), Aleppo, Syria, pp. 1-6.

18. Hodel DR \& Pittenger DR (2003). Date palm establishment. Palms 47(4): 191-200.

19. Popoola KOK (2013). Application of selected bioinsecticides in management of $O$. surinamensis (Coleoptera: Silvanidae) on Phoenix dactylifera (date) fruits. Nature and Sci 11(1): 110-115.

20. Baliga MS, Baliga BRV, Kandathil SM, Bhat HP \& Vayalil PK (2011). A review of the chemistry and pharmacology of the date (Phoenix dactylifera L.) fruits Food Res Inter 44: 1812-1822.

21. Carpenter JB (1981). Improvement of traditional date culture. Date palm J 1 : 1-16.

22. Pricket AJ Muggleton $\mathbf{J} \&$ Llewellin JA (1990). Insecticide resistance in populations of $O$. surinamensis and $C$. ferrugineus from grain stores in England and Wales. Brighton Crop Protec. Conf Pests and Disease 3: 1189-1194.

23. Beckel H, Lorini I \& Lazzari S (2007). Rearing method of Oryzaephilus surinamensis (L.) (Coleoptera; Silvanidae) on various wheat grain granulometry. Revista Brasileira de Entomologia 51(4):501505

24. Jacob TA \& Fleming DA (1990). The effect of humidity on development and survival of the immature stages of strains of $O$. surinamensis (L.) (Coleoptera: Silvanidae) at constant temperature. J Stored Product Res 26(3): 163-167.

25. Kilpatrick A.L Zungoli PA \& Benson EP (2004). Saw-toothed grain beetle. Cooperative extension service. Dept Entomol Clemson Uni pp. 46.

26. Jatoi FA, Sahito HA, Kousar T, Mangrio WM \& Shah ZH (2020). Biology, morphology and taxonomy of Lesser Date Moth, Batrachedra amydraula (Lepidoptera: Batrachedridae) under two different temperatures. Pure and Appl Biol 9(1): 1137-1147. 